\title{
Consumerism at work and its relationship to employees' personal goals, self-concept clarity, well-being and growth mindset
}

\begin{abstract}
BACKGROUND
Consumerism at work is a new concept. It is linked to materialism and consumption experience, which is why its relations with people's well-being, self-concept clarity, life aspirations and growth mindset are not obvious. The phenomenon can be manifested as obtaining documents confirming acquired qualifications and professional experience by frequent changes of workplace not motivated by a real need, but rather a desire of collecting. Consumerism at work consists of three dimensions: external attestation of competence, orientation towards self-improvement and exploratory orientation, which are related to extrinsic motivation. It is a phenomenon observed contemporarily and may be attributable to changes in the labor market.
\end{abstract}

PARTICIPANTS AND PROCEDURE

The aim of the article is to explore consumerism at work and to examine the relationship between the phenomenon, employees' personal goals, self-concept clarity, well-being and growth mindset. For that purpose, two studies were conducted among employees using a paper-pencil survey. There were 206 participants in the first study and 91 in the second one. In the new method, the Consumerism at Work Scale, the Aspirations Index, the Self-Concept Clarity Scale, the Growth Mindset Questionnaire and Ultra-Short Scales for measuring subjective well-being were used.

\section{RESULTS}

The study results show that consumerism at work is negatively related to self-concept clarity and positively related to extrinsic goals. Nonetheless, there are no relations between consumerism at work, well-being and a growth mindset.

\section{CONCLUSIONS}

It can be concluded that consumerism at work is a negative phenomenon in the context of employee's self-concept clarity, and that it is associated with materialistic goals, while it is not related to growth mindset and well-being.

\section{KEY WORDS}

well-being; self-concept clarity; personal goals; growth mindset; consumerism at work 


\section{BACKGROUND}

The culture of consumerism concerns the impact of mass consumption on everyday life, which leads to focusing all social activities on the collection and consumption of an increasing number and type of commodities and experiences (Featherstone, 1983). Gathering and consuming goods and experiences is considered to be a way to enhance well-being in life (Stanca \& Veenhoven, 2015). In the culture of consumption, the value of an individual is determined by what he owns and consumes (Kasser, 2002); the ability to sell and impress others, as well as the need for continuous change, is esteemed as well (cf. Cushman, 1990). With the consolidation of the consumerism culture there arise more and more questions about its consequences in various areas of human life, including work. One of those questions concerns correlates of the phenomenon resulting from the impact of the culture of consumption on work, known as consumerism at work. Consumerism at work manifests in concentrating on a continuous search for new experiences and collecting experiences related to work as well as gathering props from those experiences in a professional setting (cf. Godlewska-Werner et al., 2014). It results from intergeneration research that with consolidation of the culture of consumption, the approach of employees to work and the type of objectives valued by them, as well as the working conditions change. Younger generations, which have grown in a strengthened consumption culture, have less appreciation for work ethics (Twenge, 2010), and want to work less than older generations and receive high wages (Twenge \& Kasser, 2013) and are more driven by extrinsic, materialist goals at work (Godlewska-Werner et al., 2020; Twenge et al., 2010). Collaterally to strengthening consumeristic attitudes in subsequent generations, there are unceasing transformations of the labor market and changes of expectations towards employers (Frese \& Fay, 2001). These shifts mean that the employee's identity is permanently altered and can be difficult to determine.

Therefore, the purpose of this paper is to answer the following questions: how does consumerism at work relate to life goals, and how does it relate to the employee's self-concept clarity, his/her attitude to development and his/her well-being?

To answer these questions, two studies were conducted. The theoretical foundations of the research and the methodology as well as the results and conclusions are described below.

\section{WORK, CONSUMPTION AND CONSUMERISM AT WORK}

The previous era of modernism was based on industry and stability. Work was a value and an obligation, and employees were involved with organizations for many years. Instead, postmodernism relates to liquidity, elasticity, a lack of routine, constant decisionmaking and, most of all, striving for joy and pleasure enabled and achieved by the consumption of goods and services (Grabowski, 2012). These social and cultural factors have significantly influenced the labor market and workplace, causing an erosion of traditional values, emergence of unrestrained economic competition, desire of an ever-increasing diversity of choice, constant change and a commercialization of many areas of life (Mróz, 2015). In the postmodern societies people spend their free time and money on consumption and are bombarded with advertisements claiming that the good life is 'the goods life' (Kasser, 2004). Consumerism influences the evaluation of work, in the postmodern times evaluated from the point of view of providing positive and pleasurable experiences (Bauman, 2006). A change of job can offer a new, fertile environment and an alternative set of duties which allows the employee to acquire new skills. The market also enhances the need for education and vocational training. New courses and postgraduate studies emerge at universities (Szczucka et al., 2012), often without a link to a professional career, by any means facilitating making a choice regarding one's further commitment or employment. Open access to unpaid higher education in Poland resulted in a devaluation of the university degree, hence the seeking of other defining qualifications in the labor market (Klimczak, 2004). In the light of information chaos and ubiquitous uncertainty it is necessary to acquire competencies that allow career planning, appropriate not only to individual abilities and knowledge, but also to the market demand.

The dominant culture in the contemporary world can be defined as one of consumption, since material assets, wealth, fame, image constitute an object of desire, and at the same time become a value and objective (Zawadzka, 2014). It is widely believed that they are a source of happiness, although this has not been confirmed in research (Kasser, 2002). The market establishes new needs, which leads to a feeling of permanent deficiency (Bauman, 2006). People are guided by the principle of immediate gratification, leaning towards what is easy and simple from what is difficult and complex, preferring to have more and as technologically advanced as possible (Zawadzka, 2014). It emerges that a manifestation of consumerism must not necessarily be only the accumulation of goods, but also the purchase of experiences (Golka, 2004; Górnik-Durose, 2010). A sign of our time has become self-marketing/personal branding associated with creating one's own image using available tools (Mróz, 2015). It also leads to building a suitable image of oneself as an employee and shaping the identity of the individual. Work is to be a source of pleasant experiences (Bauman, 2006), which is why it is so easy
Consumerism at work 
for us to make decisions regarding the change of employer. Other than that, the labor market raises educational needs related to professional development (Szczucka et al., 2012), which is why so many people are looking for other qualifying features (Klimczak, 2004).

The socio-cultural and technological changes described above have contributed to the recognition of a phenomenon described as consumerism at work.

Consumerism at work is a concept introduced by

Dorota

GodlewskaWerner,

Aleksandra Mąkinia,

Anna Maria

Zawadzka,

Paulina

Falkowska Godlewska-Werner et al. (2014) to define an amassing of work experience unjustified by genuine needs that can manifest itself in an excessive acquisition of evidence of participation in courses, training or other activities for developing particular competencies and frequent job changes, seeking new opportunities not only for a higher salary, but also for the sake of change itself. Fortuna (2018) defines a very similar phenomenon when people attend different courses without specific needs, as in the case of educational tourism.

Its severity is influenced by the level and dynamic of the social and economic transformations, values, attitudes, and aspirations either on the broader or individual level and can be expressed in the expectations towards work and the organization, as well as a specific mode of action. The accumulation of work experience and completed training, courses, studies, can bring most advantage if applied in an appropriate context. The implications of a thoughtless career path may be maladjustment to the market demand, despite possessing numerous proofs of competences, skills and knowledge in multiple domains. This happens due to the limited utility of superficial or not well-grounded knowledge, which devalues with time. Frequent job changes as a way to gain substantial experience dominate over longer employment and patience towards expected results. Such attitude undermines loyalty between the companies and workers and weakens their mutual trust. What is more, taking further training and educational opportunities may produce a persistent dissatisfaction of achievement, since the market is continuously generating new needs. All these factors negatively influence the individuals' well-being and their growth potential.

Hitherto little attention has been paid to the described object of study. Karczewska (2016) indicated globalization and consumerism as determinants of changes and risk at work, underlining opportunities and threats. Significant consequences included the obligation of continuous development, the pressure of being always informed and the destructive influence of work-life imbalance on one's physical and mental health.

Grabowski (2012; Grabowski \& RachwaniecSzczecińska, 2016) in his publications links the changes in work ethic with the values central to the working environment and the contemporary consumer culture. He analyzed the relationships between work engagement, the attitudes towards occupation and work ethic, and distinguished four types of employees with regard to work ethics, the level of centrality of work in one's life, valuing hard work, self-fulfillment, aversion to wasting time, self-reliance and realization at work prosocial values.

In an explorational study conducted among university students, Godlewska-Werner et al. (2014) demonstrated that the participants perceive that gathering of experiences (internships, volunteering) increases their chances of finding an interesting job. It also plays a moderate role in creating one's professional image.

\section{PERSONAL GOALS AND SELF-CONCEPT CLARITY}

There are theoretical and empirical grounds to investigate the relationship between consumerism at work, personal goals and self-concept clarity (SCC).

Personal goals described by Kasser and Ryan (1993), grounded in self-determination theory, are types of aims for which people strive and aspire. The major distinction based on their content is the division into intrinsic and extrinsic aspirations. Intrinsic goals are congruent with the need for relatedness, autonomy and competence, i.e. universal needs, whose realization brings satisfaction and fulfilment. The goals situated at the opposite end of the continuum are concerned with obtaining social approval and rewards, and are often means to realizing other plans; they include financial success, image and popularity (e.g. Sheldon et al., 2004). If the pursuit of self-acceptance, affiliation and community is associated with higher well-being, while financial success is associated with the opposite. The more that materialistic values are at the center of aspirations, the poorer is the quality of life (Kasser, 2002, 2004, 2016; Kasser \& Kanner, 2004), and the more frequent are social comparison and violating one's principles or sensibilities (Sheldon et al., 2004). Moreover, individuals who favored financial success over other goals demonstrated higher control orientation, i.e. influencing and attuning to extrinsic factors in the organization of their motives (Kasser \& Ryan, 1993). This can lead to superficial satisfaction and denial of intrinsic needs, and therefore hinder self-actualization. The meta-analysis proves that materialism described by materialist values, beliefs and goals correlates significantly and negatively with well-being, and the relationship is stronger than the investigated correlation between well-being and materialism described by the desire for money or financial success (Dittmar et al., 2014). However, its relationship depends on types of well-being outcomes. It has the largest impact on risky health and consumer behaviors and negative self-appraisals, and the weakest one on life satisfaction and negative affect. 
In research conducted in Poland, Czerw (2013) found a strong relationship in the hedonic-autotelic attitude which is negatively correlated with the drive to prosperity, indicating that the stronger the satisfaction at work and its intrinsic value, the weaker the attention to a higher salary, promotion or other external well-being attributes coming from the job role or position.

Self-concept clarity is a construct introduced by Campbell that describes the extent to which selfbeliefs are clearly and confidently defined, internally consistent and temporally stable. It references a structural component of self-concept clarity, i.e. how knowledge components and self-beliefs are organized. In one of the early studies it was demonstrated that individuals with low self-esteem have a less clearly defined and temporally stable self-concept than those with high self-esteem (Campbell, 1990). In terms of adjustment, SCC correlates negatively with neuroticism, negative affectivity, anxiety and depression (Campbell et al., 2003). Mittal (2015) investigated the role of SCC in consumer behavior, and he points out that low SCC promotes susceptibility to interpersonal influence, materialism, use of shopping as escape, use of products as bolsters and postpurchase doubt. The link between SCC and career choice has been identified by Arnold and Masterson (1987), but after almost 40 years and a lack of continuity in this field of research, the conclusion that career exploration fosters self-concept certainty should be treated with caution, given the current excess of degree and career choices and other opportunities.

The consumer culture has an impact on transmitting the strive for extrinsic aspirations and it happens to the detriment of intrinsic needs. One can predict that if associated with the lack of clear, consistent and stable self-beliefs, the former values will also be applied in the working environment and when projecting one's career path.

\section{TYPES OF MINDSETS AND EMPLOYEE WELL-BEING}

People vary in their approach to tasks, success and failure. The assumption of some is that the characteristics given to us once and for all define how we act and how we are perceived and judged, while others believe that the outcomes are dependent on the input of labor and resulting effort (Dweck, 2019). The model developed by Dweck and Leggett (1988) presents two response patterns related to achievements: the helpless pattern and the mastery-oriented pattern. The helpless pattern is typical of avoiding challenges with a noticeable quick surrender in case of failure and hence the feeling of negative emotions associated with it. These are characteristics typical of people with a fixed mindset (Dweck, 2019). Such individuals focus on their unique features and do not feel the need to nurture or develop them. In their judgment, it is the world and others who should change. Of course, the results are important to them, since that is how they strengthen their belief in their superiority and value. However, they limit their actions to a minimum and avoid difficult tasks, so as not to undermine their competences in the event of failure (Ehrlinger et al., 2016).

In turn, the mastery pattern is associated with focusing on the challenge, which is characteristic for people oriented on development. People with a growth mindset are characterized by satisfaction from the activity itself as well as great determination, persistence and diligence manifested in actions, which effectively brings them closer to success (Yeager \& Dweck, 2012; Dweck, 2019). The main impulse for development is the discrepancy between the point at which one is currently and the point where one would like to be. This discrepancy is a reason for tension that can be minimized by developing one's own competences (Keating \& Heslin, 2015).

In the case of people with a growth mindset, an individual chooses tasks with a higher level of difficulty, tests their abilities and strives at developing their competences, whilst feeling positive emotions (Dweck, 2019). It is observed that in this pattern, failure is a trigger for further self-development. It constitutes motivation for harder work, modification of past actions and introduction of new ones. As a result of such a process, the individual develops his/her skills and enriches his/her experience. A growth mindset is related to achievement motivation, since it is assumed that it depends, among other things, on the manner of interpreting failure and success (cf. Zimbardo, 1999). Realization of an objective is possible when the individual has high expectations towards their competences, and undertaking actions contributes to growth (Elliot \& Church, 1997). A growth mindset is not about achieving a goal for itself or about getting comparable or better results than others, nor even about avoiding embarrassment, as described by Elliot and Church (1997). The motive is to exceed one's abilities (Dweck, 2019), while the focus on sustainability triggers unethical behavior and competition.

\section{CORRELATES OF CONSUMERISM AT WORK}

Consumerism at work is a new concept. It can be observed as an effect of changes in the labor market and it is linked with unjustified collection of certificates, attending courses and changing workplace (Godlewska-Werner et al., 2014). It is related to materialism and consumption experience, which is why its relations to people's goals, self-concept clarity, mindset and well-being are not obvious.

The contemporary world demands permanent changes and the ability to impress others by an in-
Consumerism at work 
dividual image (cf. Cushman, 1990). Therefore a way of creating an image by changing workplaces or attending courses seems to become more required. Employers have imposed higher expectations, which leads to a constant rivalry also in the area of raising competences (Goszczyńska, 2010). When choosing a job or a form of development, an individual can be guided by extrinsic motives, such as, above all, the desire to be better than others, the satisfaction of other people, e.g. parents, proving their value to others, or prestige, and not intrinsic motives such as doing what they like, pleasure, satisfaction, readiness for development or a sense of happiness (Zawadzka et al., 2020). However, it may negatively impact the sense of identity, which in turn is related to maintaining physical health (Campbell et al., 2003). This is related to self-concept clarity, a construct denoting the degree of consistency and stability of the individual's assertions about themselves which positively correlates with self-esteem (Campbell, 1990). Low self-concept clarity can lead to vulnerability to the influence of others, materialism and the purchase of goods to strengthen identity (Mittal, 2015); therefore it can be assumed that an entity characterized by low intensity of the clarity of self will focus on extrinsic factors to strengthen the self and thus pursue extrinsic goals also in the professional field.

As we look at consumerism at work as another example of consumerism, it is clear that there are some negative consequences of the consumer culture for the individual, e.g. an increasing level of narcissism (Twenge \& Kasser, 2013), experiencing less positive emotions, lower vitality (Górnik-Durose, 2010) or reduced life satisfaction (Zawadzka, 2014; Zawadzka et al., 2013). For all that, if we treat it as an experiential purchase, it can be assumed that it could increase well-being and lead to long-lasting satisfaction (Carter \& Gilovich, 2010). That is why deeper exploration of the phenomena is needed for a better definition and comprehension of the construct. According to Golka (2004), a manifestation of consumerism is the collection of goods of material and nonmaterial services not resulting from any need as a manifestation of a striving to happiness and prestige. That is why consumerism at work has the characteristics of materialistic aspirations. The possession of goods plays a paramount role here. In such a situation, material goods and other extrinsic criteria are an indicator of one's value. In case of failure, there is a threat to selfesteem (Fromm, 1996).

The pursuit of materialistic goals reduces life satisfaction, self-actualization and energy (Zawadzka, 2014), and has a negative impact on school performance and limits perseverance (Ku et al., 2014). However, the purchase of experiences has a positive effect on building relationships with others, gives a longer lasting sense of satisfaction, and increases the sense of happiness (Van Boven \& Gilovich, 2003). The rea- sons for shopping should also be included here. If these are autonomous rationales and constitute an integral part of the self, they are beneficial for the individual, but if the consumer only depends, e.g. on recognition, then the relationship will be the opposite (Zhang et al., 2013). Autonomic reasons are based on intrinsic motivation and the need to gain a locus of control or self-development, which is why an increase in well-being can be observed (Kasser, 2002). Therefore, the question should be posed whether the search for development-friendly experiences, e.g. by taking on challenges and changing jobs, can increase the level of happiness (Godlewska-Werner et al., 2014).

Murphy and Dweck (2016) stress that both types of mindsets, growth and fixed, are determined by different consumer behavior and product preferences because they differ in goals, and therefore it can be assumed that consumerism at work can also be associated with attitudes. A positive mindset and an active attitude in the enterprise's endeavors are among the characteristic features in a development-oriented attitude (Dweck, 2019). Since mastery-oriented people are more persistent in pursuing their goal, as they derive satisfaction from the activity itself, it may mean that they are characterized by lower consumerism at work, because they do not seek external confirmation of their competences.

In view of these doubts, the aim of the article it to explore the phenomenon and to evaluate the relation between some aspects of consumerism at work and life aspirations, self-concept clarity, well-being and growth mindset. In order to describe the phenomenon of consumerism at work in the context of self-concept clarity, life goals, well-being and growth mindset, the question was raised whether there is a relationship between them.

\section{STUDY 1}

\section{PARTICIPANTS AND PROCEDURE}

The study investigates the relationships between consumerism at work, personal goals and self-concept clarity. In study 1, referring to the presented concepts and research results of predecessors indicating the relationship between the culture of consumption and variations in the nature of work, changing requirements for the employee, his/her professional identity (Frese \& Fay, 2001) and changes of dominant life goals (cf. Godlewska et al., 2020; Twenge, 2010; Twenge et al., 2010; Twenge \& Kasser, 2013), two research hypotheses were formulated:

$\mathrm{H} 1$ : Consumerism at work will be negatively related to self-concept clarity.

$\mathrm{H} 2$ : Consumerism at work will be positively related to importance of extrinsic life goals. 
The study was conducted among 206 white-collar workers of the business sector aged 20-54 $(M=34.41$, $S D=8.75), 112$ women $(54.5 \%)$ and 93 men $(45.4 \%)$. Participants had at least secondary education (15.5\%) and occupied the positions of office and managerial staff at various levels. The selection was random, and the sample size was determined based on the completeness of the filling.

The study was conducted using a paper-pencil survey. The study involved the use of the Consumerism at Work Scale constructed for the needs of the study, the Aspiration Index (Grouzet et al., 2005, in the adaptation of Górnik-Durose et al., 2018) and the SelfConcept Clarity Scale (Campbell, 1990, in the adaptation of Błażek et al., 2019). The Consumerism at Work Scale is a new method, which is still being tested.

\section{MEASURES}

The Consumerism at Work Scale. The construction of the Consumerism at Work Scale comprised a few stages. The pilot study was conducted via the Internet among 28 young Polish students in the age of 20-27 (having experience as an employee). The participants received the following instructions along with the definition of consumerism at work (the format of response was open-ended): "The purpose of the following survey is to gather information about a phenomenon observable recently in the labor market. Consumerism at work is defined as amassing of work experience unjustified by genuine needs. It may manifest itself in (a) excessive acquisition of evidence of participation in courses, training or other activities for developing particular competencies, (b) frequent job changes, seeking new opportunities not only for a higher salary, but also for the sake of change itself. Please name further examples (e.g. of behavior, attitude, belief) of consumerism at work. They can be your own observations, convictions, experience related to current or former workplace, or previous conversations".

The statements of the Consumerism at Work Scale were constructed based on the participants' answers. The initial version of the questionnaire consisted of 31 statements. The tool was then evaluated by three expert judges. The compatibility indicator expressed by Kendall's $W$ equaled $W=.722$. The current version consists of 18 items (see Appendix 1). The number of items was reduced after consultations with the judges and after statistical analysis. Following the proper study, an exploratory analysis was conducted to distinguish the components of consumerism at work $(N=206)$. Based on the screen plot, the twofactor model did not fit the data, while 4 dimensions were identified. However, with 4 factors the rotation did not reach sufficient convergence, so their number was reduced to 3 . Subsequently, items that presented a weak correlation within the factors were removed from further analyses $(r<.45)$, as well as those occurring in two of the components. The value of the measure of sampling adequacy, the Kaiser-Meyer-Olkin (KMO) statistic, was .690. The total explained variance of the 3 factors equaled $38.7 \%$. Regarding the reliability statistics, they are $\alpha=.76$ for the first factor, $\alpha=.62$ for the second factor and for the third: $\alpha=.65$.

The analysis conducted on the group of 297 persons showed a good fit of the three-factor model to the dataset $(\mathrm{CMIN} / \mathrm{DF}=1.565$, RMSEA $=.044$ $(\mathrm{LO} 90=.032, \mathrm{HI} 90=.055), \mathrm{PCLOSE}=.814, \mathrm{CFI}=.912$, GFI $=.930)$. The correlations of the tested model with the factors ranged from .40 to .90 .

The questionnaire measures three factors of consumerism at work: 1 - orientation on external attestation of competence (9 items), 2 - orientation on self-development (4 items), 3 - exploratory orientation (5 items). For all factors, the estimated values of Cronbach's $\alpha$ are acceptable (orientation on external attestation of competence $\alpha=.80$, orientation on self-development $\alpha=.63$, exploratory orientation $\alpha=.64)$. Two of the factors correspond directly to the consumerism at work definition mentioned at the beginning, but one - orientation on self-development - shows the pressure on continuous development of competences because of clarification requirements and it relates to extrinsic motivation.

Orientation on external attestation of competence is the conviction of value brought by earned certificates and diplomas, reinforcing of one's own sense of competence through collecting certificates and the pursuit to acquire them, regardless of their substantive value. It means also treating the gained experiences as a resource used in the competitive labor market. It is related to a certain pride of advancement, even if it does not entail an actual change of duty.

Orientation on self-development demonstrates ambitious goal setting, the feeling of being subject to the pressure of continuous improvement, the conviction of necessity of taking additional responsibilities in order to be successful, high self-efficacy, proactive attitude, engaging in the organization and satisfaction of having many duties and being constantly busy.

The exploratory orientation is associated with the sense of an overwhelming abundance of alternatives and an inability to prioritize, and decision-making aligned to one's professional profile or personal interests. The individual frequently changes jobs in view of new experiences. He also takes part in job interviews despite the lack of actual interest, and explores and exploits the labor and education market.

In the current study, consumerism at work was calculated by adding the results from three subscales, since based on CFA there can be observed one model-fitted latent factor (Consumerism at Work) which consists of observable variables.
Consumerism at work 
The Aspirations Index (Grouzet et al., 2005, in the adaptation of Górnik-Durose et al., 2018). The scale contains 23 items, which concern intrinsic (selfacceptance, affiliation and health), extrinsic (which include money and image) and transcendent (which include community and spirituality) aspirations. The respondents answer on a 5-point scale regarding the extent to which they consider the statement about values and goals to be valid, where 1 means it is not important to me at all, and 5 means it is very important to me. The dependability of individual factors in the presented study ranged from $\alpha=.74$ to $\alpha=.82$.

The Self-Concept Clarity Scale (Campbell, 1990, in the adaptation of Błażek et al., 2019). The tool contains 12 questions about beliefs about oneself (e.g. "I can change my mind about myself from day to day"). The respondent provides answers to questions on a 7-point scale, where 0 means I definitely disagree and 6 means I definitely agree. Reliability in the current study was $\alpha=.85$.

\section{RESULTS}

Means, standard deviations and reliabilities for all tested variables are shown in Table 1 .

\section{Table 1}

Means, standard deviations and reliabilities for tested variables

\begin{tabular}{lrrr}
\hline Variables & $M$ & \multicolumn{1}{c}{$S D$} & $\alpha$ \\
\hline 1. Consumerism at work & 52.02 & 10.62 & .63 \\
2. Self-concept clarity & 44.69 & 7.82 & .85 \\
3. Intrinsic goals & 4.21 & 0.44 & .74 \\
4. Extrinsic goals & 3.35 & 0.63 & .79 \\
5. Transcendence goals & 3.26 & 0.70 & .82 \\
\hline
\end{tabular}

Table 2 presents correlations between all tested variables. As it can be seen, consumerism at work was significantly negatively correlated with self-concept clarity and it was also significantly positively correlated with employee's intrinsic goals and extrinsic goals.

The relationships between consumerism at work and sex, consumerism at work and age and consumerism at work and transcendence goals were not significant.

Linear regression analysis (method: enter) was conducted to test the hypothesis that consumerism at work is predicted by each of the self-concept clarity and workers' goals. Four variables were entered as predictors (along with sex and age as covariates), $8 \%$ of the variance in consumerism at work was accounted for $\left(R=.32, R^{2}=.10\right.$, adjusted $R^{2}=.08$, $F(6,198)=3.76, p=.001)$. As can be seen in Table 3, consumerism at work was significantly negatively associated with self-concept clarity and positively with workers' extrinsic goals.

Intrinsic goals and transcendence goals as well as age and sex of worker were not statistically significant predictors of consumerism at work.

\section{STUDY 2}

\section{PARTICIPANTS AND PROCEDURE}

After conducting study 1 , from which it results that consumerism at work is associated with a lowered self-concept clarity and enhanced extrinsic objectives, which is characteristic for materialism (Mittal, 2015), study 2, which was of an explorative nature, was conducted. It was aimed at determining whether the correlates of consumerism at work are growth mindset and well-being. Based on the research of predecessors which showed that consumerism is associated with materialism (Kasser, 2016; Kasser \& Kanner, 2004) and lowered personal and social well-being (Bauer et al.,

\section{Table 2}

Correlations between all study variables

\begin{tabular}{|c|c|c|c|c|c|c|}
\hline Variables & 1 & 2 & 3 & 4 & 5 & 6 \\
\hline \multicolumn{7}{|l|}{ 1. Consumerism at work } \\
\hline 2. Self-concept clarity & $-.18^{* *}$ & & & & & \\
\hline 3. Intrinsic goals & $.16^{*}$ & .03 & & & & \\
\hline 4. Extrinsic goals & $.27^{* *}$ & $-.16^{*}$ & $.41^{* * *}$ & & & \\
\hline 5. Transcendence goals & .00 & -.08 & $.15^{*}$ & -.04 & & \\
\hline 6. Sex & .02 & -.06 & .08 & .09 & $.25^{* * *}$ & \\
\hline 7. Age & -.13 & .04 & -.08 & $-.17^{* *}$ & .11 & .08 \\
\hline
\end{tabular}

Note. ${ }^{*} p<.05,{ }^{* *} p<.01,{ }^{* * *} p<.001$. 
Table 3

Summary of linear regression analysis predicting consumerism at work

\begin{tabular}{lccccc}
\hline Variables & B & SE & $\beta$ & $t$ & $p$ \\
\hline Sex & -.01 & .29 & -.004 & -0.05 & .959 \\
Age & -.01 & .14 & -.08 & -1.19 & .237 \\
Self-concept clarity & -.15 & .01 & -.15 & -2.18 & .031 \\
Intrinsic goals & .08 & .07 & .08 & 1.02 & .311 \\
Extrinsic goals & .20 & .08 & .20 & 2.57 & .011 \\
Transcendence goals & -.004 & .08 & -.004 & -0.06 & .951 \\
\hline
\end{tabular}

Consumerism at work
2012; Dittmar et al., 2014; Kasser, 2016; Zawadzka, 2014; Zawadzka et al., 2013) and that material goals are negatively related to orientation on mastery $(\mathrm{Ku}$ et al., 2014), it was asked whether there is a relationship between consumerism at work and mental wellbeing, as well as growth mindset. Because it was an explorative study, no hypotheses were made to assume the correlation between consumerism at work and growth mindset. But according to literature mentioned before, hypothesis H3 may be formulated that consumerism at work will be negatively related to well-being.

The study involved 91 people, including 66 women $(72.5 \%)$ and 25 men $(27.5 \%)$. The selection was random, and the sample size depended on the completeness of the filling. The participants were professionally active individuals aged 19-66 $(M=41.00$, $S D=13.19)$, having secondary $(47.3 \%)$, higher $(44 \%)$ and vocational (8.8\%) education. The respondents included people holding managerial positions (9.9\%) and others $(90.1 \%)$.

The method used in the study was paper and pencil survey. The questionnaires used for the study were the Consumerism at Work Scale described in the previous study, the Growth Mindset Questionnaire (NNR) and the Ultra-Short Scale for measuring subjective well-being in the adaptation of Atroszko et al. (Atroszko et al., 2015a; Atroszko et al., 2015b; Atroszko et al., 2017).

\section{MEASURES}

Growth Mindset Questionnaire. The used tool contains 11 items on the approach to difficult tasks, reaction to failure and search for feedback. The scale was constructed for the purpose of measuring orientation on self-development understood as a positive phenomenon, as assuming that mastery-oriented people are characterized by approaching tasks as challenges, deriving satisfaction from the implementation of challenging tasks and determination (Yeager \& Dweck, 2012; Dweck, 2019). There is no pressure, only a will- ing to be better so intrinsic motivation can be observed. An inspiration for the creation of the scale was the Dweck concept, but the questions were developed based on a mastery orientation without considering the dimension of persistence of Dweck (2019), who assumes that both attitudes occur in every person; therefore the goal was to select only those behaviors that testify to preparedness for development.

The respondents answer the questionnaire on a scale from 1 (I strongly disagree) to 5 (I strongly agree). The analysis conducted on the 399-person group showed a good fit of the two-factor model to the dataset $(\mathrm{CMIN} / \mathrm{DF}=3.042$, $\mathrm{RMSEA}=.07$ $(\mathrm{LO}=.059, \mathrm{HI}=.084), p=.003, \mathrm{CFI}=.894, \mathrm{GFI}=.936)$.

There are two factors: types of tasks $(\alpha=.74)$ and gathering information about the possibility of improvement $(\alpha=.71)$. The correlations of the tested model with the factors ranged from .60 to .77 . The first factor defines types of tasks chosen by individuals, how difficult and demanding they are. The latter shows preferences towards gathering information during task realization and analyzing situations in terms of usability of obtained information to improve the individual's work. In the current study, growth mindset was calculated by adding the results of two subscales.

Ultra-Short Scales for measuring subjective well-being. Ultra-Short Scales for measuring subjective wellbeing constructed by Skevington et al. (2004) in the adaptation of Atroszko et al. (2015a, b, 2017) contain 4 questions on various aspects of well-being. Those are: self-esteem, a general sense of quality of life, life satisfaction and the meaning of life.

The self-assessment question measures the strength of the overall level of self-satisfaction ("How satisfied are you with yourself?") on a 9-point scale from 1 (very dissatisfied) to 9 (very satisfied). The question about the general sense of quality of life ("How would you rate the quality of your life?") has a 9-point scale from 1 (very poor) to 9 (very good). Questions about satisfaction with life ("How much do you enjoy life?") and meaning of life ("To what ex- 
Table 4

Means, standard deviations and reliabilities for tested variables

\begin{tabular}{lccc}
\hline Variables & $M$ & \multicolumn{1}{c}{$S D$} & $\alpha$ \\
\hline 1. Self-esteem & 6.42 & 1.39 & .85 \\
2. Quality of life & 6.79 & 1.23 & \\
3. Satisfaction with life & 5.47 & 1.75 & \\
4. Meaning of life & 5.98 & 1.88 & \\
$\begin{array}{l}\text { 5. External attestation } \\
\quad \text { of competence }\end{array}$ & 34.53 & 4.91 & .65 \\
$\begin{array}{l}\text { 6. Orientation towards } \\
\quad \text { self-improvement }\end{array}$ & 14.89 & 3.19 & \\
7. Exploratory orientation & 13.39 & 4.14 & \\
8. Growth mindset & 41.48 & 6.71 & .84 \\
\hline
\end{tabular}

Table 5

Correlations between all study variables

\begin{tabular}{lrrrr}
\hline Variables & 1 & 2 & 3 & 4 \\
\hline $\begin{array}{l}\text { 1. Consumerism } \\
\quad \text { at work }\end{array}$ & & & & \\
2. Well-being & .10 & & & \\
3. Growth mindset & .17 & $.22^{*}$ & & \\
4. Sex & .07 & .10 & -.10 & \\
5. Age & -.14 & -.01 & .07 & -.15 \\
\hline Note. ${ }^{*} p<.05$. & & & &
\end{tabular}

tent do you feel that your life has meaning, sense?") are in the format of answers on a 9-point scale from 1 (not at all) to 9 (extremely strongly). The current study analyzed the aggregate score of psychological well-being on 4 scales. The reliability of well-being measurement in the current study was $\alpha=.85$.

\section{RESULTS}

Calculations were performed using SPFF Statistics software. Descriptive statistics for individual variables in study 2 are provided in Table 4.

To obtain answers to the question regarding the relationship between consumerism at work and a growth mindset and physical well-being, Pearson's correlation analysis was performed. It demonstrated no statistically significant relationship between consumerism at work and other variables, while a positive relationship was found between the growth mindset and well-being, which, however, was not the subject of our considerations (Table 5).

\section{DISCUSSION}

In the conducted study 1 , the formulated hypotheses were confirmed. Consumerism at work is positively associated with both a lack of clarity of self (H1) and a pursuit of extrinsic-materialistic goals (H2). Exploratory study 2 , in which the relationship between consumerism at work and well-being and growth mindset were examined, showed no significant relationship between the studied variabThe statistical analyses carried out showed that extrinsic goals are predictors of consumerism at work. There was no significant correlation between consumerism at work and growth mindset, probably because extrinsic-materialistic goals drive the activities of employees, rather than their intrinsic motives.

The obtained results related with a negative dependency between self-concept clarity and consumerism at work are confirmed in the literature in the context of consumerism in the broad sense (cf. Mittal, 2015). This means that an entity with low selfconcept clarity demonstrates a lack of knowledge of needs, an absence of crystallized values, and therefore susceptibility to the influence of others. In addition, the research describes a positive relationship between self-concept clarity and goal orientation (Błażek et al., 2019), which means that people characterized by consumerism at work may have a lower skill in constructing clear goals, and therefore they may need support from outside. Consequently, it may be more difficult to achieve intrinsic goals because a person can focus on further specifying the self. Extrinsic goals consist of money and image (Grouzet et al., 2005), which is why the person who builds his/her portfolio is guided by aspirations to be admired also in a material context. The main motive for the individual then becomes securing attractiveness as a potential employee.

To date, research has shown that people accumulate goods and experience to increase their well-being (Stanca \& Veenhoven, 2015), but ultimately high materialism is associated with lower satisfaction (see Kasser, 2004, 2016; Kasser \& Kanner, 2004; Zawadz$\mathrm{ka}, 2014)$. However, the results of research conducted by the authors do not indicate this relationship. This may be due to the fact that it seems difficult to compare and value professional qualifications and experience. Moreover, people who acquire items and services overactively can feel happy only in the short term (Golka, 2004). The lack of an assumed relationship between consumerism at work and well-being (H3) can also be explained by the fact that consumerism at work (unjustified actions related to certifying one's competences, striving for self-improvement and exploratory orientation) can be a way to deal with the situation of volatility and uncertainty in the contemporary labor market (Frese \& Fay, 2001; Goszczyńska, 2010). 
Similarly, the lack of a dependence between consumerism at work and a growth mindset may result from the changes observed in the labor market, which require from employees constant adaptation to new conditions, whereby extrinsic motives are adopted by the individual as their own over time. The relationship may not yet be observable because this process is still ongoing. On the one hand, growing in the consumer culture strengthens the preferences to take more easily achievable actions (Zawadzka, 2014) and less perseverance (Twenge, 2010), which is the opposite of the growth mindset, but on the other hand, striving to obtain qualifying features requires more activity from the individual (Klimczak, 2004) regardless of their motive.

As a result of the authors' research, an additional result was obtained indicating the relationship between growth mindset and well-being. A growth mindset can be understood as a will to improve oneself and development, and hence it improves wellbeing (Zawadzka \& Szabowska-Walaszczyk, 2014). Well-being can be seen as a kind of reward for providing a variety of experiences (Czapiński, 2005). Furthermore, it may indicate that an individual undertaking an effort related to the development and optimal exploitation of resources can cope with challenging situations, which strengthens the sense of meaning (Ryff, 1989). Happy people view positive events, among others, as a result of the action of their predispositions resulting from the internal locus of control (Argyle \& Martin, 1991), which may be characteristic of people with a growth mindset.

Summarizing the conducted research, it can be concluded that consumerism at work is a negative phenomenon in the context of employee's self-concept clarity, and that it is associated with materialistic goals, while it is not related to growth mindset and well-being.

The presented research was explorative, as far as the authors are aware; to date no research is being conducted on consumerism at work and its correlates. Therefore, there is a need for further investigation on larger groups of employees from different generations and professional groups, and in view of the positions held by them. Moreover, it is worth including other measures of well-being in subsequent studies - measuring both satisfaction but also a sense of meaning at work or social well-being.

Research from the employer's perspective could be a great contribution to learn more about the essence of consumerism at work. It is worth considering in this study how employers, managers or recruiters perceive the amount of received training, the quality or their compliance with the desired profession. Perhaps in this case, quantity and diversity are also significant, and not quality and cohesiveness. Organizing in-house training alone may prove to be an important area to explore. We should seek answers to such questions as: how participants are selected for training for employees, and whether employers send their employees for training according to individual preferences or generally, regardless of how newly acquired competences will be reflected in the current occupation. In this case, the impact of pressure exerted by the work environment (superiors, HR departments or other) and cultural conditions could be considered. In the case of young individuals who are just entering the labor market, it is worth examining what factors affect overactive gaining of experience and certificates. In addition, satisfaction with life should be regarded in the perspective of its duration, while in the case of self-assessment, further research should separate it into explicit and latent. It would also be worthwhile to consider the intercultural context of consumerism at work in subsequent studies to investigate whether it is a universal or characteristic phenomenon for cultures that have experienced rapid political and economic changes.

A broader definition of consumerism at work could also prove helpful during recruitment. Awareness of this phenomenon will eliminate candidates focused on gaining "collected" experience and will help in selecting those whose activity related to the expansion of competences performs a development function and which is characterized by coherence. The presented attitudes may prove useful in the proper selection of chosen upskill forms and in taking the accurate direction in developing one's career. A robust approach to the topic of competence development can prevent wasting potential and human resources. It also gives the opportunity to create more experts in given fields, whose quality of services could increase considerably.

\section{References}

Argyle, M., \& Martin, M. (1991). The psychological causes of happiness. In F. Strack, M. Argyle, \& N. Schwarz (Eds.), Subjective well-being. An interdisciplinary perspective (pp. 77-100). Pergamon Press.

Arnold, J., \& Masterson, A. (1987). Self-concept certainty, career exploration and readiness for career decision-making amongst undergraduate students. British Journal of Guidance \& Counselling, 15, 92-96. https://doi.org/10.1080/03069888708251647

Atroszko, P. A., Bagińska, P., Mokosińska, M., Sawicki, A., \& Atroszko, B. (2015a). Validity and reliability of single item self-report measures of general quality of life, general health and sleep quality. In M. McGreevy \& R. Rita (Eds.), Proceedings of the 4th Biannual CER Comparative European Research Conference (pp. 207-211). Sciemcee Publishing.

Atroszko, P. A., Krzyżaniak, P., Sendal, L., \& Atroszko, B. (2015b). Validity and reliability of single item
Consumerism at work 
self-report measures of meaning in life and satisfaction with life. In M. McGreevy \& R. Rita (Eds.) Proceedings of the 4th Biannual CER Comparative European Research Conference (pp. 212-215). Sciemcee Publishing

Atroszko, P. A., Sawicki, A., Sendal, L., \& Atroszko, B. (2017). Validity and reliability of single-item selfreport measure of global self-esteem. In M. McGreevy \& R. Rita (Eds.), Proceedings of the 7th Biannual CER Comparative European Research Conference (pp. 120-123). Sciemcee Publishing.

Dorota

GodlewskaWerner, Aleksandra Mąkinia, Anna Maria Zawadzka, Paulina Falkowska

Bauer, M. A., Wilkie, J. E., Kim, J. K., \& Bodenhausen, G. V. (2012). Cuing consumerism: Situational materialism undermines personal and social wellbeing. Psychological Science, 5, 517-523. https:// doi.org/10.1177/0956797611429579

Bauman, Z. (2006). Praca, konsumpcjonizm i nowi ubo$d z y$ [Work, consumerism and the new poor]. Wydawnictwo WAM.

Błażek, M., Besta, T., \& Kaźmierczak, M. (2019). Związek klarowności ja z formalną charakterystyką działań celowych oraz cechami osobowości [Selfconcept clarity, characteristics of the goal oriented activity, and personality traits]. Polskie Forum Psychologiczne, 24, 292-307. https://doi.org/10.14656/ PFP20190302

Campbell, J. D. (1990). Self-esteem and clarity of the self-concept. Journal of Personality and Social Psychology, 59, 538-549. https://doi.org/10.1037/00223514.59.3.538

Campbell, J. D., Assanand, S., \& Paula, A. D. (2003). The structure of the self-concept and its relation to psychological adjustment. Journal of personality, 71, 115-140. https://doi.org/10.1111/1467-6494. t01-1-00002

Carter, T. J., \& Gilovich, T. (2010). The relative relativity of material and experiential purchases. Journal of Personality and Social Psychology, 98, 146-159. https://doi.org/10.1037/a0017145

Cushman, P. (1990). Why the self is empty: Toward a historically situated psychology. American Psychologist, 45, 599-611. https://doi.org/10.1037/0003066X.45.5.599

Czapiński, J. (2005). Psychologia pozytywna [Positive psychology]. Wydawnictwo Naukowe PWN.

Czerw, A. (2013). Co ludzie myślą o pracy zawodowej? Konstrukcja metody diagnozującej postawy wobec pracy [What do people think about work? Construction of the method diagnostic of attitudes toward work]. Psychologia Spoteczna, 8, 219-233.

Dittmar, H., Bond, R., Hurst, M., \& Kasser, T. (2014). The relationship between materialism and personal well-being: a meta-analysis. Journal of Personality and Social Psychology, 107, 879-924. https://doi.org/10.1037/a0037409

Dweck, C. (2019). Nowa psychologia sukcesu [A new psychology of success]. Muza SA.
Dweck, C. S., \& Leggett, E. L. (1988). A social-cognitive approach to motivation and personality. Psychological Review, 95, 256-273. https://doi.org/10. 1037/0033-295X.95.2.256

Ehrlinger, J., Mitchum, A. L., \& Dweck, C. S. (2016) Understanding overconfidence: Theories of intelligence, preferential attention, and distorted selfassessment. Journal of Experimental Social Psychology, 63, 94-100. https://doi.org/10.1016/j.jesp. 2015.11.001

Elliot, A. J., \& Church, M. A. (1997). A hierarchical model of approach and avoidance achievement motivation. Journal of Personality and Social Psychology, 72, 218-232. https://doi.org/10.1037/00223514.72.1.218

Featherstone, M. (1983). Consumer culture: an introduction. Theory, Culture and Society, 1, 4-9. https://doi.org/10.1177/026327648300100301

Fortuna, P. (2018). Subiektywna psychologia biznesu [Subjective psychology of business]. Gdańskie Wydawnictwo Psychologiczne.

Frese, M., \& Fay, D. (2001). Personal initiative: an active performance concept for work in the 21st century. Research in Organizational Behavior, 23, 133187. https://doi.org/10.1016/S0191-3085(01)23005-6

Fromm, E. (1996). Niech się stanie cztowiek. Z psychologii etyki [Man for himself: an inquiry into the psychology of ethics]. PWN.

Godlewska-Werner, D., Celińska, S., \& Nieckarz, Z. (2014). Konsumpcjonizm w pracy znakiem naszych czasów? [Consumerism at work is a sign of our times?]. In A. M. Zawadzka, M. Niesiobędzka, \& D. Godlewska-Werner (Eds.), Kultura konsumpcji - wartości, cele, dobrostan. Psychologiczne aspekty zjawiska [Culture of consumption - values, goals, well-being. Psychological aspects of the phenomenon] (pp. 159-176). Liberi Libri.

Godlewska-Werner, D., Peplińska, A., Zawadzka, A. M., \& Połomski, P. (2020). Work motives in the context of generational differences, gender differences, and preferred values. Polish Psychological Bulletin, 51, 116-125.

Golka, M. (2004). Wiara i rozczarowanie w cywilizacji konsumpcyjnej [Faith and disappointment in consumerist society]. Ruch Prawniczy, Ekonomiczny i Socjologiczny, 66, 261-270.

Goszczyńska, M. (2010). Transformacja ekonomiczna w umystach i zachowaniach Polaków [Economic transformation in the minds and behavior of Poles]. Wydawnictwo Naukowe Scholar.

Górnik-Durose, M. (2010). Kupowanie rzeczy, kupowanie doświadczeń - nowe zjawiska w zachowaniach konsumenckich [Buying things, buying experiences - new phenomena in consumer behavior]. In M. Goszczyńska \& M. Górnik-Durose (Eds.), Psychologiczne uwarunkowania zachowań ekonomicznych. Przedsiębiorczość - pieniądze - konsumpcja [Psychological determinants of economic be- 
havior. Entrepreneurship - money - consumption] (pp. 209-234). Difin.

Górnik-Durose, M., Jach, Ł., \& Langer, M. (2018). Intrinsic - extrinsic - transcendent. A triarchic model of goal contents: introduction and validation. Current Issues in Personality Psychology, 6, 1-16. https://doi.org/10.5114/cipp.2017.66890

Grabowski, D. (2012). Miejsce pracy w kulturze konsumpcji. Etos pasjonującej i interesującej pracy jako forma jej konsumpcji [Workplace in the culture of consumption. The ethos of passionate and interesting work as a form of its consumption]. In M. Górnik-Durose \& A. M. Zawadzka (Eds.), W supermarkecie szczęścia. O różnorodności zachowań konsumenckich w kontekście jakości życia [At the happiness supermarket. About the diversity of consumer behavior in the context of quality of life] (pp. 67-77). Difin.

Grabowski, D., \& Rachwaniec-Szczecińska, Ż. (2016). Etyka pracy i wartości realizowane w pracy a zaangażowanie pracowników [Work ethic, the working values and work commitment]. Czasopismo Psychologiczne, 22, 81-90. https://doi.org/10.14691/ CPPJ.22.1.81

Grouzet, F. M. E., Kasser, T., Ahuvia, A., Dols, J. M. F., Kim, Y., Lau, S., Ryan, R. M., Saunders, S., Schmuck, P., \& Sheldon, K. M. (2005). The structure of goal contents across 15 cultures. Journal of Personality and Social Psychology, 89, 800-816. https://doi.org/10.1037/0022-3514.89.5.800

Karczewska, A. (2016). Globalizacja i konsumpcjonizm jako uwarunkowania zmian i potencjalne źródła zagrożeń w sferze pracy [Globalization and consumerism as conditioning and potential sources of threats in a workplace]. Zeszyty Naukowe Politechniki Częstochowskiej. Zarządzanie, 24, 38-46. https://doi.org/10.17512/znpcz.2016.4.2.04

Kasser, T. (2002). The high price of materialism. MIT Press.

Kasser, T. (2004). The good life or the goods life? Positive psychology and personal well-being in the culture of consumption. In P. A. Linley \& S. Joseph (Eds.), Positive psychology in practice (pp. 55-67). John Wiley \& Sons Inc.

Kasser, T. (2016). Materialistic values and goals. Annual Review of Psychology, 67, 489-514. https://doi. org/10.1146/annurev-psych-122414-033344

Kasser, T., \& Kanner, A. D. (Eds.) (2004). Psychology and consumer culture: The struggle for a good life in a materialistic world. American Psychological Association.

Kasser, T., \& Ryan, R. (1993) A dark side of the American dream: Correlates of financial success as a central life aspiration. Journal of Personality and Social Psychology, 65, 410-422. https://doi. org/10.1037/0022-3514.65.2.410

Keating, L. A., \& Heslin, P. A. (2015). The potential role of mindsets in unleashing employee engagement.
Human Resource Management Review, 25, 329-341. https://doi.org/10.1016/j.hrmr.2015.01.008

Klimczak, K. (2004). Efektywność polskiego szkolnictwa wyższego na tle europejskiego rynku pracy [Effectiveness of Polish higher education against the background of the European labor market]. Acta Universitatis Lodziensis. Folia Oeconomica, 180, 125-138.

Ku, L., Dittmar, H., \& Banerjee, R. (2014). To have or to learn? The effects of materialism on British and Chinese children's learning. Journal of Personality and Social Psychology, 106, 803-821. https://doi. org/10.1037/a0036038

Mittal, B. (2015). Self-concept clarity. Exploring its role in consumer behavior. Journal of Economic Psychology, 46, 98-110. https://doi.org/10.1016/j. joep.2014.11.003

Mróz, B. (2015). Wszystko na sprzedaż? Pułapki i manowce konsumpcjonizmu [Is everything for sale? Pitfalls and byways of consumerism]. Psychologia Ekonomiczna, 7, 25-36. https://doi.org/10.15678/ PJOEP.2015.07.02

Murphy, M. C., \& Dweck, C. S. (2016). Mindsets shape consumer behavior. Journal of Consumer Psychology, 26, 127-136. https://doi.org/10.1016/j.jcps.2015.06.005

Ryff, C. D. (1989). Happiness is everything, or is it? Explorations on the meaning of psychological well-being. Journal of Personality and Social Psychology, 57, 1069-1081. https://doi.org/10.1037/ 0022-3514.57.6.1069

Sheldon, K. M., Ryan, R. M., Deci, E. L., \& Kasser, T. (2004). The independent effects of goal contents and motives on well-being: It's both what you pursue and why you pursue it. Personality and Social Psychology Bulletin, 30, 465-486. https://doi. org/10.1177/0146167203261883

Skevington, S. M., Lotfy, M., \& O'Connell, K. A. (2004). The World Health Organization's WHOQOL-BREF quality of life assessment: Psychometric properties and results of the international field trial. A report from the WHOQOL group. Quality of Life Research, 13, 299-310. https://doi.org/10.1023/ B:QURE.0000018486.91360.00

Stanca, L., \& Veenhoven, R. (2015). Consumption and happiness: an introduction. International Review of Economics, 62, 91-99. https://doi.org/10.1007/ s12232-015-0236-x

Szczucka, A., Turek, K., \& Worek, B. (2012). Ksztatcenie po szkole. Uczenie się dorostych, inwestycje w kadry w przedsiębiorstwach, instytucje szkoleniowe [Post-school education. Adult learning, investment in human resources in enterprises, training institutions]. Polska Agencja Rozwoju Przedsiębiorczości.

Twenge, J. M. (2010). A review of the empirical evidence on generational differences in work attitudes. Journal of Business and Psychology, 25, 201210. https://doi.org/10.1007/s10869-010-9165-6
Consumerism at work 
Twenge, J. M., Campbell, S. M., Hoffman, B. J., \& Lance, C. E. (2010). Generational differences in work values: Leisure and extrinsic values increasing, social and intrinsic values decreasing. Journal of Management, 36, 1117-1142. https://doi. org/10.1177/0149206309352246

Twenge, J. M., \& Kasser, T. (2013). Generational changes in materialism and work centrality, 19762007: Associations with temporal changes in societal insecurity and materialistic role modeling.

Dorota

GodlewskaWerner, Aleksandra Mąkinia, Anna Maria Zawadzka, Paulina Falkowska Personality and Social Psychology Bulletin, 39, 883897. https://doi.org/10.1177/0146167213484586

Van Boven, L., \& Gilovich, T. (2003). To do or to have? That is the question. Journal of Personality and Social Psychology, 85, 1193-1202. https://doi. org/10.1037/0022-3514.85.6.1193

Yeager, D. S., \& Dweck, C. S. (2012). Mindsets that promote resilience: When students believe that personal characteristics can be developed. Educational Psychologist, 47, 302-314. https://doi.org/10. 1080/00461520.2012.722805

Zhang, J. W., Howell, R. T., \& Caprariello, P. A. (2013). Buying life experiences for the "right" reasons: a validation of the motivations for experiential buying scale. Journal of Happiness Studies, 14, 817842. https://doi.org/10.1007/s10902-012-9357-z

Zawadzka, A. M. (2014). Wartości, cele i dobrostan w kulturze konsumpcji [Values, goals and wellbeing in the culture of consumption]. In A. M. Zawadzka, M. Niesiobędzka, \& D. Godlewska-Werner (Eds.), Kultura konsumpcji - wartości, cele, dobrostan. Psychologiczne aspekty zjawiska [Culture of consumption - values, goals, well-being. Psychological aspects of the phenomenon] (pp. 15-37). Liberi Libri.

Zawadzka, A. M., Iwanowska, M., \& Borchet, J. (2020). The role of teen materialism, parents' materialism, and teen self-esteem and family SES in teen achievement goal orientations. Przegląd Psychologiczny, 63, 331-348.

Zawadzka, A. M., \& Szabowska-Walaszczyk, A. (2014). Does self-improvement explain well-being in life and at workplace? Analysis based on selected measures of well-being. Polish Psychological Bulletin, 45, 134-141. https://doi.org/10.2478/ ppb-2014-0018

Zawadzka, A. M., Sęk, T., \& Szabowska-Walaszczyk, A. (2013). Jak nadużywanie władzy wiąże się z dobrostanem jednostki? [Power abuse and well-being]. Chowanna, 1, 65-84.

Zimbardo, P. (1999). Psychologia i życie [Psychology and life]. Wydawnictwo Naukowe PWN. 
Orientation on external attestation of competence

1. It is good to obtain as many certificates (and other proofs of completed training, courses, voluntary work) as possible, even if I am not sure whether they may be useful in life.

2. I do not mind passing up a good opportunity (i.e., training, educational course) if the offer is not in line with my career path or interests.

3. Each subsequent certified training is valuable, regardless of the knowledge and skills I acquire.

4. I am proud of any kind of promotion, even if my responsibilities and duties remain the same.

5. Having certificates from single trainings/courses that are not thematically related is worthless.

6. Getting a certificate immediately strengthens my sense of competence.

7. Having many certificates and other proofs of completed training indicates an employee's value on the labor market.

8. If the knowledge gained from a training course is minimal, it does not make sense to include this item in your $\mathrm{CV}$.

9. I include in my CV only the most important of my professional and educational experiences.

Orientation on self-development

1. I often feel the pressure of self-development.

2. Taking extra responsibilities and obligations is essential to achieve professional success.

3. In the associations I belong to, I show initiative and undertake tasks that are valuable for these organizations.

3. Being constantly busy and having many responsibilities gives me satisfaction.

\section{Exploratory orientation}

1. When a wide range of alternatives occurs, I often feel like getting involved in all of them at once.

2. I often change my job/organization because of I want new experiences.

3. In my opinion, frequent job changes (e.g., every six months) are an opportunity for a better use of individual potential.

4. I often participate in job interviews even if I do not feel like changing my job.

5 . I often get confused about my priorities when facing a wide range of alternatives. 